\title{
NEW TECHNOLOGIES AND SCIENCE TEACHERS EDUCATION WITHIN THE CONTEXT OF DISTANCE LEARNING: A Case Study for the University of Lagos
}

\author{
Ademola Johnson ADEWARA \\ Distance Learning Institute, \\ University of Lagos, NIGERIA \\ Olufunke LAWAL \\ Distance Learning Institute, \\ University of Lagos, NIGERIA
}

\begin{abstract}
The Open and Distance Learning (ODL) education for science teachers is seen as a solution to the problems of equity and access to teacher education in Nigeria. It is used to provide cost-effective Science Teacher Education, and to train large numbers of teachers within a short period of time. The need for training science teachers through ODL systems is becoming more critical and necessary. The study explored the contribution of Science Teacher Education within the context of Open and Distance Learning in the following areas: time spent on electronics devices, skill development in the use of computer technologies and applications, Extent of use of IT in courses and course management system features. The study used a survey method. Stratified sampling technique was adopted. Two hundred and fifty (250) questionnaires were sent out and one hundred and seventy three (173) were returned. The result shows that that there is a significant positive correlation between science teachers education within the context of Open Distance Learning and time spent on electronics devices, skill development in the use of computer technologies and application, Extent of use of IT in courses and course management system features at $R=0.688,0.625$, $0.165,0.607,0.500$, with the $p$ value of $<0.05$ level of significance. This result implies that increase on each of these variables will further enhance Science Teacher Education.
\end{abstract}

Keywords: CD-ROM, interactive Video, Information Technology, In-service teacher, inquirycentered, pedagogic skills.

\section{INTRODUCTION}

Constant improvement in education in Nigeria is required in the area of teaching and learning from the primary school level up to the university. The adopted or inherited system of education needs to be redesigned from face to face method of teaching to new technology-based methods for a more effective delivery:

The old system of education seems to be expensive in terms of material, physical structure and maintenance requirements Badenhorst, JC and de Beer, J K (2004). Abdullahi, S.A. (2007) and Ogbeba J. A. (2010) observed that most teachers emphasise theory rather than 
practical aspects of science subjects while most of them lack adequate knowledge of subject matter and the competence to deliver.

Also, there are few classrooms where teachings are done with practical demonstrations.

When such demonstrations are occasionally used, they are often mostly carried out by the teacher, and this makes students passive. There are also few traditional hands-on (practical) classes. Science lessons in most Nigerian classrooms are yet to be structured, guided and students-directed Omoifo, C. N. (2012).

Poor quality of science teachers in terms of adequate knowledge base and pedagogic skills is another factor identified to influence students' performance. The teacher's academic qualifications and knowledge of subject matter, competencies and skills, and commitment have a great impact on the teaching/learning process. There should be proper staffing of schools in terms of quality and quantity.

There should also be provision of modern teaching-learning resources such as the Internet, computers, interactive board and a variety of science materials to engage learners in inquiry-centered science learning. To attain the desired level, there is the need to embrace distance learning education for science teachers as a solution to problems of equity and access to quality education and rapid technological and economic development of the country.

Distance education has been used to provide cost-effective science teacher education, and it can be used to train and provide quality large numbers of teachers within short periods of time. This calls for the re-positioning of the universities in Nigeria to distribute knowledge production systems by using available tools and resources such as ICT to improve their activities. This paper attempts to investigate the use of new technologies in the training of in-service science teachers of Distance Learning Institute, University of Lagos.

\section{LITERATURE REVIEW}

Learning in Information Age requires new teacher role. Teachers cannot depend only on the traditional tools such as chalk, textbooks, overhead video projectors and other types of traditional instructional materials to teach students the skills required for survival in the Information Age.

They have to use technologies of the day such as computers, interactive video, CD-ROM, satellite communications; these entail new teacher roles.

The development and use of these Information and Communications Technology (ICT) devices and ideas to promote human learning is the hall-mark of an ICT-driven curriculum. Effective implementation of this type of curriculum requires new teacher roles regarding the 'what' and 'how' of instruction. The era when teachers were traditionally considered as "directors, lecturers and disseminators of information" Rhodes, D. (1990) is over. The new roles of teachers include being managers and leaders of instruction. Rhodes, D. (1990) Opines that teachers should assume the roles of seekers, long-range planners, collaborators, researchers and mentors/mentees. However a teacher cannot assume these roles unless he/she is at home with the ICT.

There has been a consistent effort in many countries to promote an ICT teacher/learner empowerment culture. In 1997, the Department for Education and Employment (DFEE) in the UK published the National Grid for Learning which is the government consulting paper 
on "extending access and making available to all learners the riches of the world's intellectual cultural and scientific heritage" (DFEE).

In Simpson, M.; Payne, F; Munro, R; and Hughes, S. (1999) also it was mentioned that appropriate targets for the development of skills in both serving and trainee teachers in Scotland were set and published by the Scottish Office Education and Industry Department in 1998. In the same year, the Teacher Training Agency in England set out guidelines and Teacher ICT literacy requirements.

McFarlane, A. (1997A) opines that between 1981 and 1994, the UK government spent up to $£ 189$ million on the development of Information Technology (IT) in schools. As regards the training of teachers, McFarlane, A. (1997A) remarks that by 1995 the Department for Education (DFE) proudly indicated that 90 percent of teachers were computer literate. Commenting on the growth of access to multimedia in schools in UK McFarlane, A. (1997B) notes that "in 1996, 35 percent of primary schools had a multimedia capable computer and some multimedia titles published in CD-ROM".

According to Olaseni, M. \& Alade, W. (2012) the Nigerian Vision 20:20 20 is an outcome of a research by the American Investment Bank which predicted that Nigeria will be in the league of $\mathbf{2 0}$ top economies based on the assessment of her abundant natural and human resources, with the assumption that these resources will be effectively managed. Based on this assumption, Nigeria launched the Vision which she hoped would place her on the path of sustained social and economic progress, and accelerate the emergence of a truly prosperous Nigeria.

Also with the fact that Nigeria is blessed with enough natural resources, there is the possibility of improving her citizens' living standards.

The science teachers' preparation would go a long way in addressing the challenges of vision 20: 20-20 and to achieve all its goals. Obanya, P. (2002), when discussing the need for quality teachers' recruitment, re -education, motivation, and retraining, described a revolutionary type of teacher as a person: who has wholeheartedly accepted the new vision of secondary education and who has internalised the underlying principles of its new pedagogy; whose teaching style is governed by flexibility and who can experiment in the face of new challenges; whose approach to specialisation is sufficiently broad to emphasise understanding and solving teaching-learning problems in favour of merely distilling codified knowledge; and who will be a willing participant in the task of continuously improving the delivery of secondary education.

For the system to have this type of science teachers, adequate preparation is necessary to intimate them with the vision 2020 and its challenges.

In order to face the challenges, Abdullahi, S.A. (2007) suggested that the new education plan should endeavour to create viable and enabling programmes amidst the challenges of private versus public education, funding, instructional methods, research, and teacher education, citizenship education programmes, and activities that have become crucial to sustaining the goals, objectives, and aspirations of the nation.

The challenges identified by the Education Sector National Technical Working Group (2009) include inability to provide unfettered access to quality education at all levels, dearth of qualified and competent teachers, little or no relevant skills in ICT and poor motivation for their acquisition, low intrinsic value for education, inadequate number of schools and 
classrooms, security of teachers and increase in students' enrolment in senior secondary schools.

Science is a core subject at all levels of education in Nigeria. Science education is also to provide a more effective preparation for citizenship. In order to achieve this, qualified and highly scientifically literate teachers are required who are well aware of their global demands for teaching with a view to engendering scientific and technological values in learners.

Omoifo, C. N. (2012) emphasised that science teachers therefore, need to recognise the nature of scientific endeavours and how it relates to science teaching if they are to help their students completely understand the content and underlying principles of science. Science teachers as a matter of interest need to be aware of national educational policies and goals in order to discharge their teaching activities towards achieving those goals whatever be their gender, type of school and school locations.

Furthermore, to achieve these objectives a school of thought suggested that the need for improvisation is a pedagogical intervention strategy that teachers may use to address similar situations by being resourceful in the making and use of locally available materials where conventional equipment and or apparatus may be inadequate or not available at all Inyega, J. and Tompson, N. (2002). Low-cost materials produced through improvisation are not an attempt to provide a watered down science education, but low cost in the mentioned sense is highly creative and highly productive, provides opportunities for creativity and development of manipulative abilities and concepts that are learnt and internalized by concrete and experience.

\section{METHOD}

A survey research method was adopted in this paper. The questionnaire had eighty-one items and the items were based on New Technologies and Science Teacher Education. The items included: demographic information, time spent on electronic devices, skill level using computer technologies and application, Information Technology, extent of use of IT in courses and course management system features.

This was administered to the Science Education Students of Open and Distance Learning Institute, University of Lagos, Akoka Nigeria. Stratified sampling technique was adopted in this research. Two hundred and fifty (250) questionnaires were sent out and only one hundred and seventy three (173) were returned. Descriptive statistics was explored for some sections of the questionnaire while regression analysis was used to explore the contribution of Science Teachers Education within the context of Open and Distance Learning to the following items:

$>$ time spent on electronics devices,

$>$ skill level using computer technologies and

$>$ application, Information Technology, extent of use of IT in courses and course management system features

The test of reliability of the responses on the 53 items in the assessment of new technologies and science teachers' education within the context of distance learning, using standardized Cronbach's Alpha is obtained as $0.904(90.4 \%)$ with mean response scale statistics of 3.04 and standard deviation (SD) of 0.759 . 
This result suggests that the instrument of evaluation is highly reliable judging from the fact that $\mathbf{9 0 . 4 \%}>\mathbf{7 0 \%}$. Similar results obtained in other sections of the questionnaire also supported that the questionnaire developed was reliable.

Data Analysis and Result

Reliability analysis of new technologies for in-service teachers by the students at DLI University of Lagos

Table: 1

Reliability Test Results of Instrument

\begin{tabular}{|c|c|c|c|c|c|c|c|}
\hline \multirow{2}{*}{$\begin{array}{l}\text { Instrument } \\
\text { Source }\end{array}$} & \multicolumn{4}{|c|}{ Scale Statistics } & \multirow{2}{*}{$\begin{array}{c}\begin{array}{c}\text { Reliability } \\
\text { Statistics }\end{array} \\
\begin{array}{c}\text { Cronbach's } \\
\text { Alpha }\end{array}\end{array}$} & \multicolumn{2}{|c|}{$\begin{array}{l}\text { Validity Statistics } \\
\text { (ANOVA) }\end{array}$} \\
\hline & $\begin{array}{c}\mathrm{N} \text { of } \\
\text { Items }\end{array}$ & Mean & STD & CV & & F-value & P-value \\
\hline Time Spent on electronics devices & 17 & 2.83 & 1.071 & 0.38 & 0.908 & 69.617 & 0.000 \\
\hline $\begin{array}{l}\text { Skill level using computer } \\
\text { technologies and application }\end{array}$ & 10 & 2.90 & 0.384 & 0.13 & 0.857 & 17.746 & 0.000 \\
\hline Information Technology & 7 & 2.65 & 0.264 & 0.10 & 0.762 & 7.586 & 0.000 \\
\hline Extent of use of IT in courses & 10 & 3.19 & 0.318 & 0.10 & 0.880 & 10.756 & 0.000 \\
\hline Course Management system features & 9 & 2.67 & 0.251 & 0.09 & 0.936 & 14.104 & 0.000 \\
\hline Pooled Data & 53 & 3.04 & 0.759 & 0.25 & 0.904 & 11.021 & 0.000 \\
\hline
\end{tabular}

Source: Field Survey, 2014. STD (Standard Deviation)

Also, the result showed that there is an internal consistency of the items in the instrument (questionnaires) used for the data collection. The validation of the reliability results of instruments is carried out using analysis of variance (ANOVA) to test if there is significance variation on how the respondents rated the items in the instrument. The results suggested that there is no significance variation on the rating of the items by respondents in the instruments at F-value $=11.021$, since P-values $=0.000<0.05$ significant level. The result is supported by coefficient of variation $(\mathrm{CV})=0.25<0.50$ threshold, implying homogeneity on how the respondents rated the items. Hence, the reliability of the instrument is significant, which validates the adequacy of the questionnaire.

Table: 2

Socio-Demographic Characteristics of Respondents

\begin{tabular}{|llrrrr|}
\hline Variables & Characteristics & Freq. & \multicolumn{1}{l}{$\%$} & Mean & Total \\
\hline Gender & Male & 95 & 54.9 & & \\
& Female & 78 & 45.1 & 173 \\
\hline Age Group & $20-29$ & 89 & 52.4 & \\
& $30-39$ & 67 & 39.4 & \\
& $40-49$ & 12 & 7.1 & \\
& $50-59$ & 2 & 1.2 & & \\
& $>=60$ & 0 & 0 & 30.2 years & 170 \\
\hline CGPA & $1.00-2.39$ & 46 & 29.5 & & \\
& $2.40-3.49$ & 55 & 35.3 & &
\end{tabular}




\begin{tabular}{|c|c|c|c|c|c|}
\hline & $\begin{array}{l}3.50-4.49 \\
4.50-5.00\end{array}$ & $\begin{array}{r}47 \\
8\end{array}$ & $\begin{array}{r}30.1 \\
5.1\end{array}$ & $2.99 \mathrm{cgpa}$ & 156 \\
\hline \multirow[t]{4}{*}{ Disciplines in Science Education } & Mathematics & 57 & 36.1 & & \\
\hline & Chemistry & 12 & 7.6 & & \\
\hline & Biology & 66 & 41.8 & & \\
\hline & PHYSICS & 23 & 14.6 & & 158 \\
\hline
\end{tabular}

Source: Field Survey 2014

The result of the demographic studies shows that $54.9 \%(95)$ are male while $45.1 \%$ (78) were females.

The age groups of the respondents were also considered in the study. The result shows that $52.4(89)$ were between the age of $20-29,39.4 \%$ (67) were between the ages of 30-39, $7.1 \%$ (12) were between the age of $40-49$ while overall average ages of the DLI students was 30.2 years.

The Cumulative Grade Point Average (CGPA) was considered in this study.

The results shows that $29.5 \%(46)$ were on third class, $35.3 \%$ (55) were in second class lower, 30.1 (47) were in second class upper and 5.1\% (8) were in first class.

The average CGPA is 2.99.The students' area of specialization/discipline was considered in this survey. The result showed that $36.1 \%$ (57) were admitted for mathematics, $7.6 \%$ (12) were chemistry, 41.8 (66) were for Biology and 14.6\% (23) were for physics.

\section{Research Hypothesis 1}

Ho: Science Teachers Education within the context of Open and Distance Learning has no significant effect on time spent on electronics devices, skill level using computer technologies and application, Information Technology, extent of use of IT in courses and course management system.

Table: 3

Pearson Correlations Analysis

\begin{tabular}{|l|r|r|r|r|r|r|r|r|r|}
\hline Variables & DV & V1 & \multicolumn{1}{|c|}{ V2 } & V3 & V4 & V5 & Mean & \multicolumn{1}{c|}{$\begin{array}{c}\text { Std. } \\
\text { Deviation }\end{array}$} & N \\
\hline $\begin{array}{l}\text { Science Teachers Education within } \\
\text { the context of Distance Learning }\end{array}$ & 1 & & & & & & 2.830 & 0.57642 & 200 \\
$\begin{array}{l}\text { Time Spend on electronics devices } \\
\text { Skill level using computer } \\
\text { technologies and application }\end{array}$ & $.688^{*}$ & 1 & & & & & 2.856 & 0.97644 & 198 \\
Information Technology & $.625^{*}$ & $.338^{*}$ & 1 & & & & 2.869 & 0.91098 & 198 \\
$\begin{array}{l}\text { Extent of use of IT in courses } \\
\text { Course Management system } \\
\text { features }\end{array}$ & $.165^{*}$ & $-146^{*}$ & -.108 & 1 & & & 2.643 & 0.75262 & 182 \\
& $.607^{*}$ & .114 & $.259^{* *}$ & $.279^{*}$ & 1 & 3.056 & 1.05790 & 177 \\
\hline
\end{tabular}

*. Correlation is significant at the 0.05 level (1-tailed). $\mathbf{R}=0.964$. $\mathbf{R}^{2}=0.929$.

The Pearson correlation result suggests that there is a significant positive correlation between Science Teachers Education within the context of the Open and Distance Learning and Time Spent on electronic devices, skill level using computer technologies and applications, Information Technology, extent of use of IT in courses and course management system features at $R=0.688,0.625,0.165,0.607,0.500$, since $p<0.05$ significant level. 
This result implied that increase on each of these variables will further enhance Science Teachers Education. This result is supported by multiple correlation at $R=0.964(96.4 \%)$, which shows positive correlation between the explanatory variables and Science Teachers Education within the context of Open and Distance Learning.

The variation accounted for in the model is given as $R^{2}=0.929(92.9 \%)$, which is the amount of information the independent variables have about the dependent variable. The model adequacy is ascertained in the ANOVA table.

Table: 4

Analysis of Variance (ANOVA)

\begin{tabular}{|c|c|c|c|c|c|}
\hline Model & Sum of Squares & df & Mean Square & F & Sig. \\
\hline Regression & 50.920 & 5 & 10.184 & 417.562 & 0.000 \\
Residual & 3.902 & 160 & .024 & & \\
Total & 54.822 & 165 & & & \\
\hline
\end{tabular}

The ANOVA table shows that the variation in the dependent variable accounted for by the model is adequate at $F=417.562, p<0.05$.

Hence the model is acceptable for result utilization and further analysis. The effect of the independent variable on the dependent variable is examined in the regression analysis.

Table: 5

Regression Analysis Coefficients

\begin{tabular}{|c|c|c|c|c|c|c|c|}
\hline \multirow[t]{2}{*}{ Model } & \multicolumn{2}{|c|}{$\begin{array}{l}\text { Unstandardized } \\
\text { Coefficients }\end{array}$} & $\begin{array}{l}\text { Standardized } \\
\text { Coefficients }\end{array}$ & \multirow[t]{2}{*}{$\mathbf{t}$} & \multirow[t]{2}{*}{ Sig. } & \multicolumn{2}{|c|}{$\begin{array}{c}\text { Collinearity } \\
\text { Statistics }\end{array}$} \\
\hline & B & Std. Error & Beta & & & Tolerance & VIF \\
\hline (Constant) & .102 & .070 & & 1.450 & .149 & & \\
\hline $\begin{array}{l}\text { Time Spend on electronics } \\
\text { devices }\end{array}$ & .332 & .013 & .563 & 24.817 & .000 & .866 & 1.155 \\
\hline $\begin{array}{l}\text { Skill level using computer } \\
\text { technologies and } \\
\text { application }\end{array}$ & .206 & .015 & .325 & 13.872 & .000 & .810 & 1.235 \\
\hline Information Technology & .099 & .018 & .129 & 5.636 & .000 & .849 & 1.178 \\
\hline $\begin{array}{l}\text { Extent of use of IT in } \\
\text { courses }\end{array}$ & .162 & .014 & .297 & 11.877 & .000 & .709 & 1.410 \\
\hline $\begin{array}{l}\text { Course Management } \\
\text { system features }\end{array}$ & .162 & .014 & .273 & 11.250 & .000 & .758 & 1.319 \\
\hline
\end{tabular}

Multiple regression analysis was used to determine the effect of the independent variables on the dependent variable. Science Teachers Education within the context of Distance Learning represents the dependent variable, while time spent on electronics devices, skill level using computer technologies and applications, Information Technology, extent of use of IT in courses, course management system features represent the independent variables. The result of the analysis reveals that all the explanatory variables are significant at $\mathrm{t}=\mathbf{2 4 . 8 1 7}, \mathbf{1 3 . 8 7 2}, \mathbf{5 . 6 3 6}, \mathbf{1 1 . 8 7 7}$ and 11.250 respectively, $\mathrm{P}<0.05$.

Hence, time spent on electronic devices, skill level using computer technologies and applications, Information Technology, extent of use of IT in courses, course management 
system features have significant direct effect on Science Teachers Education within the context of Open and Distance Learning.

The adequacy of these results is supported by Variance Inflation Factor (VIF), which shows no significant multi-collinearity since the values are all less than 2 . The regression model is given as:

$D V=0.102+0.332 V 1+0.206 V 2+0.099 V 3+0.162 V 4+0.162 V 5$

The model implies that when new technologies/IT skill possession is at zero level, science teachers' education will increase by $\mathbf{1 0 . 2 \%}$.

A unit increase in time spent on electronics devices will propel a growth of $33.2 \%$ on science teachers' education, the introduction of computer technologies and application skills will increase science teachers' education by $20.6 \%$, Information Technology will boost science teachers' education by $9.9 \%$, the use of IT will boost a growth of $16.2 \%$ while course management system features will lead to a growth of $16.2 \%$. It can be deduced from the standardized coefficients that time spent on electronic devices has the greatest significance direct effect on Science Teachers Education within the context of Open and Distance Learning with $56.3 \%$.

This is followed by skill level using computer technologies and applications with $32.5 \%$, extent of use of IT in courses with $29.7 \%$, course management system features with $27.3 \%$ and Information technology with $12.9 \%$.

\section{Research Hypothesis 2}

Ho: The time spent on electronic devices, skill level using computer technologies and application, Information Technology, extent of use of IT in courses, course management system features have no significant effect on CGPA.

Table: 6

Descriptive Statistics and Pearson Correlations

\begin{tabular}{|c|c|c|c|c|c|c|}
\hline & CGPA & $\begin{array}{c}\text { Time } \\
\text { Spent on } \\
\text { electronics } \\
\text { devices }\end{array}$ & $\begin{array}{l}\text { Skill level using } \\
\text { computer } \\
\text { technologies and } \\
\text { application }\end{array}$ & $\begin{array}{l}\text { Information } \\
\text { Technology }\end{array}$ & $\begin{array}{l}\text { Extent of } \\
\text { use of IT } \\
\text { in } \\
\text { courses }\end{array}$ & $\begin{array}{c}\text { Course } \\
\text { Management } \\
\text { system } \\
\text { features }\end{array}$ \\
\hline CGPA & 1 & & & & & \\
\hline $\begin{array}{l}\text { Time Spend on } \\
\text { electronics } \\
\text { devices }\end{array}$ & -.063 & 1 & & & & \\
\hline $\begin{array}{l}\text { Skill level using } \\
\text { computer } \\
\text { technologies and } \\
\text { application }\end{array}$ & -.054 & $.338^{*}$ & 1 & & & \\
\hline $\begin{array}{l}\text { Information } \\
\text { Technology }\end{array}$ & $.179^{*}$ & $-.146^{*}$ & -.108 & 1 & & \\
\hline $\begin{array}{l}\text { Extent of use of } \\
\text { IT in courses }\end{array}$ & $.185^{*}$ & .114 & $.259^{*}$ & $.279^{*}$ & 1 & * \\
\hline $\begin{array}{l}\text { Course } \\
\text { Management } \\
\text { system features }\end{array}$ & $.199^{-}$ & .002 & $.171^{*}$ & $.260^{*}$ & $.462^{*}$ & 1 \\
\hline
\end{tabular}

*. Correlation is significant at the 0.05 level. $\mathbf{R}=0.262$. $\mathbf{R}^{2}=0.069$. 
The Pearson correlation result suggests that there is a significant correlation between CGPA and Information Technology, Extent of use of IT in courses, Course Management system features at $R=-0.179,-0.185,-0.199$, since $p<0.05$ significant level.

This result implied that CGPA has an inverse relationship with each of the variables.

Table: 7

Analysis of Variance (ANOVA)

\begin{tabular}{|ll|c|c|c|c|c|}
\hline Model & & Sum of Squares & df & Mean Square & F & Sig. \\
\hline \multirow{4}{*}{1} & Regression & 9.969 & 5 & 1.994 & 2.355 & 0.043 \\
& Residual & 135.480 & 160 & .847 & & \\
& Total & 145.448 & 165 & & & \\
\hline
\end{tabular}

Dependent Variable: CGPA

The ANOVA table shows that the variation in the dependent variable accounted for by the model is adequate at $\mathbf{F}=\mathbf{2 . 3 5 5}, \mathrm{p}<\mathbf{0 . 0 5}$.

Hence the model is acceptable for result utilization and further analysis. The effect of the independent variable on the dependent variable is examined in the regression analysis.

Table: 8

Regression Analysis Coefficients

\begin{tabular}{|c|c|c|c|c|c|c|c|}
\hline \multirow[t]{2}{*}{ Model } & \multicolumn{2}{|c|}{$\begin{array}{c}\text { Unstandardized } \\
\text { Coefficients }\end{array}$} & \multirow{2}{*}{$\begin{array}{c}\begin{array}{c}\text { Standardized } \\
\text { Coefficients }\end{array} \\
\text { Beta }\end{array}$} & \multirow[t]{2}{*}{$\mathbf{t}$} & \multirow[t]{2}{*}{ Sig. } & \multicolumn{2}{|c|}{$\begin{array}{c}\text { Collinearity } \\
\text { Statistics }\end{array}$} \\
\hline & B & $\begin{array}{l}\text { Std. } \\
\text { Error }\end{array}$ & & & & Tolerance & VIF \\
\hline (Constant) & 4.503 & .415 & & 10.841 & .000 & & \\
\hline $\begin{array}{l}\text { Time Spend on electronics } \\
\text { devices }\end{array}$ & -.070 & .079 & -.072 & -.882 & .379 & .866 & 1.155 \\
\hline $\begin{array}{l}\text { Skill level using } \\
\text { computer technologies } \\
\text { and application }\end{array}$ & -.001 & .087 & -.001 & -.015 & .988 & .810 & 1.235 \\
\hline Information Technology & -.167 & .103 & -.134 & -1.618 & .108 & .849 & 1.178 \\
\hline $\begin{array}{l}\text { Extent of use of } \\
\text { IT in courses }\end{array}$ & -.072 & .080 & -.081 & -.894 & .373 & .709 & 1.410 \\
\hline $\begin{array}{l}\text { Course Management } \\
\text { system features }\end{array}$ & -.122 & .085 & -.126 & -1.437 & .153 & .758 & 1.319 \\
\hline
\end{tabular}

The result of the analysis reveals that all the explanatory variables are not significant at $\mathbf{5 \%}$ level.

Hence, Time Spent on electronics devices, Skill level using computer technologies and application, Information Technology, Extent of use of IT in courses, Course Management system features have no significant effect on CGPA. 
The adequacy of these results is supported by Variance inflation factor (VIF), which shows no significant multi-collinearity since the values are all less than 2

\section{Research Hypothesis 3}

Ho: There is no significant difference between the CGPA effect and the IT knowledge of the students.

$H_{1}$ : There is a significant difference between the CGPA effect and the IT knowledge of the students.

Table: 9

Knowledge of Information Technology * CGPA

\begin{tabular}{|c|c|c|c|c|c|c|c|}
\hline & \multicolumn{4}{|c|}{ CGPA } & \multirow[t]{2}{*}{ Total } \\
\hline & & & $\begin{array}{c}1.00- \\
2.39\end{array}$ & $\begin{array}{c}2.40- \\
3.49\end{array}$ & $\begin{array}{c}3.50- \\
4.49\end{array}$ & $\begin{array}{c}4.50- \\
5.00\end{array}$ & \\
\hline \multirow{8}{*}{$\begin{array}{l}\text { Knowledge } \\
\text { of IT }\end{array}$} & do not use & count & 0 & 0 & 1 & 0 & 1 \\
\hline & 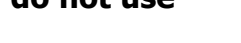 & expected & .3 & .4 & .3 & .1 & 1.0 \\
\hline & Namellod & count & 11 & 14 & 10 & 6 & 41 \\
\hline & very unskillea & expected & 12.1 & 14.5 & 12.4 & 2.1 & 41.0 \\
\hline & unskilled & count & 31 & 31 & 32 & 1 & 95 \\
\hline & unskilled & expected & 28.0 & 33.5 & 28.6 & 4.9 & 95.0 \\
\hline & & count & 4 & 10 & 4 & 1 & 19 \\
\hline & skmIIed & $\begin{array}{l}\text { Expected } \\
\text { Count }\end{array}$ & $\begin{array}{l}5.6 \\
46\end{array}$ & $\begin{array}{l}6.7 \\
55\end{array}$ & $\begin{array}{l}5.7 \\
47\end{array}$ & $\begin{array}{c}1.0 \\
8\end{array}$ & $\begin{array}{r}19.0 \\
156\end{array}$ \\
\hline Total & & Expected & 46.0 & 55.0 & 47.0 & 8.0 & 156.0 \\
\hline
\end{tabular}

Table: 10

Chi-Square Tests

\begin{tabular}{|l|r|r|r|}
\hline & Value & Df & Asymp. Sig. \\
\hline Pearson Chi-Square & $16.690^{\mathrm{a}}$ & 9 & .044 \\
Likelihood Ratio & 15.744 & 9 & .072 \\
Linear-by-Linear & 1.467 & 1 & .226 \\
Association & 156 & & \\
N of Valid Cases & & & \\
\hline
\end{tabular}

The Chi-square test result indicates that the cumulative grade point average has significant effect on knowledge of IT with a Chi-square value $=16.690$ with degree of freedom (9), $p<$ 0.05. Hence, respondents with good CGPA are expected to have better knowledge of IT.

\section{CONCLUSION}

The result shows that science teachers trained at Distance Learning Institute, University of Lagos under the new technologies of e-learning, e-teaching have shown significant improvement in content knowledge and perception of pedagogical styles. Also, in terms of numbers, Open and Distance Learning has a positive record that meets the needs of the school system. The Pearson correlation result suggests that there is a significant positive correlation between Science Teachers Education within the context of Distance Learning and Time Spent on electronic devices, skill level using computer technologies and application. Information Technology, extent of use of IT in courses and course management system features at $R=0.688,0.625,0.165,0.607,0.500$, since $p<0.05$ significant level. This result 
implied that increase on each of these variables will further enhance Science Teachers Education.

The result is supported by multiple correlation at $R=0.964(96.4 \%)$, which shows positive correlation between the explanatory variables and Science Teachers Education within the context of Distance Learning. The variation accounted for in the model is given as $\mathbf{R}^{2}=0.929$ $(92.9 \%)$, which is the amount of information the independent variables have about the dependent variable Also, the correlation between CGPA and Information Technology, extent of use of IT in courses, course management system features at $R=-0.179,-0.185,-0.199$, at $p<0.05$ showed that CGPA has an inverse relationship with each of the variables.The experience has demonstrated that open and distance learning can be effectively deployed for science teacher education if students were motivated, with good tutorial support, and viable logistics.

\section{RECOMMENDATIONS}

This paper has established the need to use Open and Distance Learning education to facilitate the training of science in-service teachers through ICT-driven pedagogies and curriculum so as to make it Information Age compliant. This is the only way to ensure that the school system produces individuals who can effectively perform desired activities in the societies. The major implication of the findings of this study is that the University of Lagos is an ICT learning environment for in-service training science teachers. Through ICT training quality teachers can be provided and there could be enough teachers for the science subjects. Also, teachers should be trained in ICT; relevant facilities should be provided and adequate building should be set up in schools. Besides, ICT can only function in an environment where there is regular supply of electricity. This implies that there should be constant supply of electricity to all our schools irrespective of location and remote.

\section{BIODATA and CONTACT ADDRESSES of the AUTHORS}

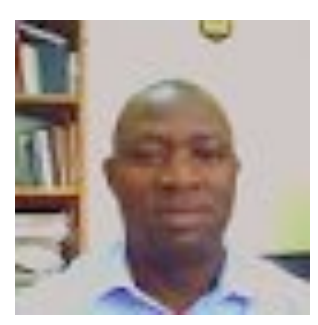

Johnson Ademola ADEWARA was born on February 23, 1969 at IjanOtun, Kwara State. He is a Senior Lecturer Statistics in Distance Learning Institute (DLI) University of Lagos, Akoka. He attended Kwara State College of Education, Oro for his National Certificate in Education (NCE). He proceeded to the University of Lagos for B. Sc (Ed) in Mathematics and M.Sc. in Statistics. He had a Ph.D. degree in Statistics at the University of Agriculture, Abeokuta Nigeria. He is a member of Nigerian Statistical Association. His area of specialization includes Multivariate Analysis, Statistical Process Control, Total Quality Management, Total Quality Control, Quality Assurance in Distance Education and Data Analysis

Ademola Johnson ADEWARA

Distance Learning Institute, University of Lagos, NIGERIA

Phone: +2348023875722

Email(s): jadewara@unilag.edu.ng, adewaraja@gmail.com 


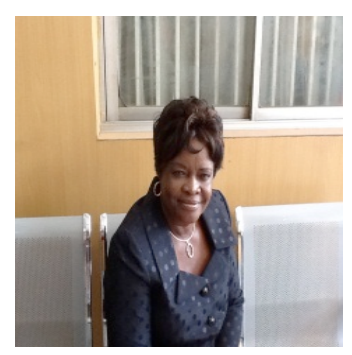

Olufunke LAWAL of the Department of Arts and Social Sciences Education, Faculty of Education, University of Lagos, Akoka holds a B.A.Ed (English Hons.) $2^{\text {nd }}$ Class Upper Division, Master of Education (M.Ed) (Curriculum Studies) and Ph.D (Literature Education). She has held the following positions: Director, Distance Learning Institute, University of Lagos, 2010 to August 2014; Dean, College of Humanities Tai Solarin University of Education, Ijagun, Ijebu-Ode, Ogun State October 2006 to November 2007 (On Sabbatical); Head Department of Curriculum Studies/Arts and Social Sciences Education, Faculty of Education, University of Lagos. August 2003 to July 2006; Consultant (Education) Unilag Consult, 2003-2006; Member, Adeniran Ogunsanya College of Education Governing Council, Ijanikin, Lagos State 2010-20131; Chairman, University of Lagos Library Committee 20082010; Member, University of Lagos Senate Academic Planning Committee 1995-1996; Resource Person, USAID, UNICEF, NTI 2001-2004 and Member and later Consultant, State Universal Basic Education Board, Lagos and Ogun States 1989-1994; 2004-2006. She is also a member of the following Professional Associations: Rock Monnteun Language Association (RMLA), U.S.A; World Council of Curriculum and Instruction (WCCI) U.S.A, Reading Association of Nigeria and International Association for the Advancement of Curriculum Studies (IAACS), U.S.A

Olufunke LAWAL

Distance Learning Institute, University of Lagos, NIGERIA

Phone: +2348023109243

Email: olufunkelus@yahoo.com

\section{REFERENCES}

Abdullahi, S. A. (2007). Education and democracy in Nigeria: Vision 2020 Retrieved October 12, 2010 from http://www.nigeriainamerica.com/articles retrieved

Badenhorst, JC and de Beer, JK (2004). Blended Learning at the Central University of Technology, Free State. Paper presented in the emerge 2004 conference on 29 June - 8, July2004,http://emerge2004.net/connect/site/UploadWSC/emerge2004/file20/emerge20 04article.doc accessed on 10 July 2007).

Huppert, J. \& Lazarowitz, R. (2002). Computer simulations in the high school: students' cognitive stages, science process skills and academic achievements in microbiology.

International Journal of Science Education 24: 803-821Mlitwa, Nhlanhla (2005). Higher Education and ICT in the Information Society: A Case of UWC.2nd Annual Conference of the Community Informatics Research Network (CIRN). 24-26 August, 2005, Cape Peninsula University of Technology (CPUT), South Africa.

Inyega, J. and Tompson, N. (2002). Change in Attitudes towards Teaching Strategies in Secondary School Teachers in Kenya Following In-service Professional Development. Paper presented at annual conference of SAETS, 2002, Kennesaw, GA.

McFarlane, A. (1997A). Where Are We And How Did We Get Here? In Angela McFarlane (Ed) Information technology and Authentic Learning. 1-12.

McFarlane, A. (1997B). Thinking about Writing in Angela McFarlane (Ed) Information technology and Authentic Learning. $108-120$.

Obanya, P. (2002). Revitalizing education in Africa. Ibadan. Stirling-Horden Publishers Ltd. 
Ogbeba J.A. (2010). Using advance organizers to improve the teaching and learning of Biology: A case for specific objectives. Journal of Educational Innovators.3 (2), $184-190$.

Olaseni, M. \& Alade, W. (2012). Vision 20:2020 and the challenges of infrastructural development in Nigeria.

Omoifo, C.N. (2012). Dance of the limits reversing the trends in science education in Nigeria.Inaugural Lecture Series 124,Benin City: University of Benin Press McFarlane, A. (1997A). Where Are We And How Did We Get Here? In Angela McFarlane (Ed) Information technology and Authentic Learning. 1-12.

Rhodes, D. (1990). Teachers on the Firing Line. Technology Revolution Comes To Education. 46ED-47ED.

Simpson, M.; Payne, F; Munro, R; and Hughes, S. (1999). Using Information and Communications Technology As A Pedagogical Tool: Who Educates the Educator? Journal of Education for Teaching 247- 261. 